УДК 140(4+540)

DOI 10.35423/2078-8142.2019.5-6.08

O. В. Кіхно,

кандидат філологічних наук, старший науковий співробітник Інституту філософії імені Г. С. Сковороди НАН України м. Київ, Украӥна e-mail: a.kihno@gmail.com ORCID: https://orcid.org/0000-0001-7329-3332

\title{
ПРАЦЯ «ЩО ТАКЕ ЙОГА?» П. Д. УСПЕНСЬКОГО ТА ФІЛОСОФІЯ ІНТЕГРАЛЬНОЇ ЙОГИ ШРІ АУРОБІНДО ГХОША (ПОРІВНЯЛЬНИЙ АНАЛІЗ)
}

Стаття пропонує список паралелей між поглядами і інтерпретаиією йоги у Успенського і поглядами Ауробіндо і Сатпрема, які теж претендували на більш глибоке і непересічне розуміння иього феномена. Праия П. Д. Успенського «Що таке йога?» писалася $і$ перероблювалася доволі тривалий час у період 1912-1934 рр. $і$ займає своє особливе місие між прачями, які в ті часи популяризували йогу для західного читача, $i$ «Синтезом йоги» Шрі Ауробіндо. Ауробіндо, вказуючи межсі аналітичного підходу, намагався дати оригінальну інтерпретачію йогічним феноменам, виходячи з власної філософської парадигми. Стаття порівнюе інтерпретацію Успенським системи раджа-йоги у зіставленні з інтегральним підходом Ауробіндо $i$ Сатпрема. Успенський відзначає, щзо людина мусить оволодіти вмінням зупиняти хід своїх думок. Своєрідна метафорична мова Успенського зіставляється у статті з яскраво поетичною метафорикою Сатпрема у його книзі, присвяченій філософії Ауробіндо. Можна зробити висновок, що Успенський ставить перед собою радше описові і більш аналітичні задачі, він шукав аутентичність в описі індійського, йогічного способу пізнання. Ауробіндо постійно шукав більш синтезуючий підхід до йоги і прагнув вийти за межі як західного раиіоналізму, так і традииійних описів йоги.

Ключові слова: йога, інтегральна йога, свідомість, ментальність, орієнталізм.

104 (C) Кіхно О. В., 2019 
Так сталося, що під час оцінки філософського доробку Шрі Ауробіндо доволі популярною залишається практика звернення до компаративістської проблематики. 3'являються дослідження, що розглядають творчість Шрі Ауробіндо у традиційному індуїстському контексті. Наприклад, у праці Дж. Ллевеліна зіставляються погляди Шрі Ауробіндо, Тілака, Ганді на соціальну етику Бгагавадгіти [9], а В. Хачзермеєр робить спробу здійснити компаративний аналіз інтроспекцій Шрі Ауробіндо у світоглядні вчення Крішни, Будди, Рамакрішни, з одного боку, та вчення Христа - $з$ іншого [6]. Не менш показовими є праці, в яких побудови Ауробіндо розглянуті в західному ідейному контексті. Так, Род Хемсел порівнює погляди Ауробіндо на людську та універсальну свідомість 3 феноменологічними побудовами Гегеля [5]. Девід Джонстон у своїх публікаціях намагається розглянути філософію інтегральної йоги Ауробіндо як у передбачуваному контексті, порівнюючи погляди мислителя з поглядами Юнга [7], так і в несподіваному вимірі, ставлячи Ауробіндо і Матір (Мірру Рішар) у ряд своєрідних світоглядних пророків сучасності поряд не лише з Юнгом, а й, наприклад, 3 Толкієном [8]. Тим більше, аналізуючи феномен інтегральної йоги Ауробіндо, вважаємо доречним звернутися до порівняння його 3 більш ідейно та практично спорідненими поглядами П. Успенського.

Засаднича праця П. Д. Успенського «Що таке йога?» писалася і перероблювалася тривалий час, у період 1912-1934 pp. Вона займає особливе місце між працями, які в ті часи популяризували йогу для західного читача - такими, як книги йога Рамачараки (Аткінсона), ідеями Вівекананди і, звичайно, «Синтезом йоги» Ауробіндо. Останній, визначаючи межі аналітичного підходу, намагався дати оригінальну інтерпретацію йогічним феноменам, виходячи 3 власної філософської парадигми. Праця Успенського цікава тим, що автор намагається вийти за межі попереднього, на його думку, поверхнєвого європейського підходу до феномена йоги і дати цьому явищу більш глибоку, більш «орієнталізовану» інтерпретацію. Водночас, можна провести чимало паралелей між поглядами і інтерпретацією йоги в Успенського і поглядами Ауробіндо і Сатпрема, які теж претендували на більш глибоке і непересічне розуміння цього феномена. 
Успенський висуває декілька тез, які можна оцінити як критику попередніх підходів до орієнтальної проблематики. Поперше, він відзначає: чимало фактів засвідчують, що крім знань, які зафіксовані у стародавніх книгах Індії, в її священних переданнях є більш «потаємне» знання, яке неможливо почерпнути 3 книг, яке не розкривається публічно, але сліди якого можна розшукати. По-друге, він стверджує, що європейська філософія, яка завжди використовувала для вивчення писемні та міфологічні джерела, «дивним чином, ніколи не досягає тих ідеалів мудрості, святості і сили, які притаманні батьківщині Упанішад» [2, с. 247].

По-третє, він постулює, що в дійсності існує не одне, а кілька невідомих Заходу індійських вчень, які тим не менше походять 3 одного спільного кореня. I, нарешті, учетверте, Успенський стверджує, що йога як сукупність систем самовиховання протистоїть всім цим відомим і невідомим вченням і теж має одну спільну світоглядну основу, яку потрібно розшукати. Таким чином, і в цьому сенсі Успенський протиставляє аналітизмові попередніх європейських підходів складну сукупність індійських шкіл йоги, спробу відшукати більш універсальну світоглядну основу для феномена йоги.

Початок праці «Що таке йога?», яка виходила як окрема книга, а пізніше, у модернізованому вигляді, була включена у працю «Нова модель Всесвіту», присвячений майже рекламному описові величезних можливостей йогів, «знання, яке безмежно збільшує їхні сили у порівнянні із силами пересічних людей» [2, с. 247]. Ауробіндо i, пізніше, Сатпрем висувають низку тез, які можуть виглядати почасти як аналогічні з ідеями Успенського, проте частогусто і як полеміка як з його твердженнями, так і з твердженнями вчителів традиційної йоги. Так, Успенський відзначає: «використовуючи сили, які дає йога, людина може йти лише в одному напрямку. Якщо вона піде іншим шляхом, сама ж йога повернеться проти неї, зупинить іiі, позбавить усіх сил i, можливо, навіть знищить іiі. У йозі зосереджена величезна сила, але ця сила може бути використана лише у певному напрямку» [2, с. 248]. Ця теза, яка уявляється очевидною для Успенського, не є догмою для Ауробіндо і Сатпрема. Інтегральна йога Ауробіндо, по-перше, ставить перед собою мету, відмінну від мети традиційних йогів, а саме 106

Institute of Philosophy of H. S. Skovoroda of NAS of Ukraine 
включення низхідної сили і повне преображення всіх рівнів психіки і самої тілесності людини, i, по-друге, ставить за мету інтегрувати різні йогічні традиції, пройти саме різними, часто взаємовиключними, шляхами.

Сатпрем зауважує, що йога Ауробіндо (пурна-йога) вирізняється саме тим, що той, хто займається традиційною йогою, кінецькінцем починає відчувати висхідну силу, яка пробуджується, i доволі грубо, в центрі Кундаліні, і світоглядно пов'язана з метою сходження свідомості і звільненням її від кайданів тіла. Йога Ауробіндо має справу з зовсім іншою енергією, яка починається 3 головних або й надрозумових (супраментальних) центрів і $є$ низхідною за своєю суттю, і це теж детерміноване світоглядними апріоріями тих, хто практикує йогу.

Успенський допомагає по-іншому поглянути на специфіку йоги Ауробіндо. Він відзначає, що для тих, хто практикує йогу, вибір однієї з класичних традицій залежить від психологічного типу людини і іiі здібностей. Успенський описує п'ять традиційних шляхів йоги:

1) Раджа-йога, або йога розвитку свідомості,

2) Джняна-йога, або йога знання,

3) Карма-йога, або йога правильних дій,

4) Хатха-йога, або йога влади над тілом,

5) Бхакті-йога, або йога правильної релігійної дії.

Традиційні описи йоги починаються 3 хатха-йоги. Успенський іде тим самим шляхом, але зауважує, що «Раджа-йога по відношенню до психічного світу людини, до іï самосвідомості, є те саме, що хатха-йога по відношенню до фізичного світу» [2, с. 259].

Людина відповідної психологічної схильності може почати зі споглядання. Якщо ми поглянемо з цієї позиції на критику Ауробіндо і Сатпремом традиційної йоги, ми відзначимо, що ця критика перш за все стосується шляхів хатха-йоги. Особливістю підходу Ауробіндо було те, що в центр він поставив певну синтезацію 3 двох традиційних йогічних систем, а саме - поєднав раджа-йогу, тобто йогу споглядання, і карма-йогу - йогу правильної дії. Перша 3 них визначила те, що він поставив у центр свідомість. Недарма книга Сатпрема, що присвячена філософії Ауробіндо, має назву «Шрі Ауробіндо або мандрівка свідомості». Іншим, не менш акту- 
альним мотивом є мотив карма-йоги - звідси весь пафос діяння «в миру», в суспільстві, звідси ж і така актуальна для Ауробіндо ідея загального спасіння і т.д. Певні тези філософії Ауробіндо та Сатпрема і слід розглядати як відповідний розвиток або й просто коментування ідей традиційних йог, інші їхні тези - суто оригінальні.

Є в Успенського тези, які відповідають ідеям філософії Ауробіндо, є, звичайно, такі, які відповідають частково, або не відповідають зовсім. Успенський твердить: «вивчення йоги неможливе 3 тією розкиданістю думок, бажань і почуттів, в якій живе пересічна людина» [2, с. 252]. I філософія Ауробіндо не лише підтримує цю звичайну для йоги тезу, а й пропонує детальну програму заспокоєння розуму та потім очищення ментального, вітального та тілесного рівнів людської свідомості.

Важливим для порівняння є подальший висновок Успенського: «Йога вимагає всієї людини, вимагає, потребує весь іiі час, всю енергію, всі думки і почуття, все їі життя. Тільки карма-йога дає людині можливість залишатися у звичайних умовах життя. Усі інші йоги вимагають негайного і повного відходу від життя, хоча б на деякий час. Вивчати йоги, за винятком карма-йоги, у звичайних умовах життя неможливо. Так само не можливо вивчати йогу без учителя, без його постійного і безпосереднього спостереження за учнем» [2, с. 252-253]. Ауробіндо і Сатпрем пропонують займатися йогою саме в гущавині людського життя i це знов таки пов’язано з особливою трансформаційною метою йоги Ауробіндо. Але складається враження, що в цьому сенсі Ауробіндо бере на озброєння і ставить у центр своєї йогічної етики саме спрямований на життя імператив карма-йоги, яка справді викликала його особливий інтерес. Згадаймо працю Ауробіндо «Ідеал кармайогіна», статті у журналі «Карма-йогін», написані у післяаліпорський час час остаточного переходу від політичної до власне йогічної діяльності. Сатпрем відзначає: «Нам потрібне життя в усій його повноті... I досягти цього блаженними медитаціями і в ідилічній атмосфері просто неможливо» [1, с. 46].

Ауробіндо формує цю спрямованість на життя ще радикальніше: «У нашому духовному усамітненні ми можемо закостеніти i виявити пізніше, що нам важко в усій повноті ізлити себе назовні і прикласти до життя наші досягнення, що стосуються вищої При108

Institute of Philosophy of H. S. Skovoroda of NAS of Ukraine 
роди. Коли ми звернемося до зовнішнього, щоб до наших внутрішніх завоювань приєднати і це царство, ми виявимо, що ми занадто звикли до суто суб'єктивної діяльності, яка на матеріальному плані неефективна. Перетворити зовнішнє життя і тіло буде надзвичайно складно... Усе відбувається так, ніби ми жили в іншому світі, світі більш широкому і більш тонкому, але не мали жодного не лише божественного впливу, а й ніякого іншого, навіть найменшого впливу на матеріальне і земне існування» [1, с. 46-47]. Уся цитата достатньо промовиста: зовнішнє життя, тіло, матеріальне і земне існування перебуває в центрі уваги Ауробіндо.

Інше принципове питання - необхідність учителя. Сам Ауробіндо не виходив із цієї обов'язковості і проходив йогічні практики, як висловивився Сатпрем, «вільним стрільцем», щоправда він мав певні проблеми із заняттями пранаямою, а безгоміння розуму встановив в основному з допомогою йогіна Бхаскара Леле. В ашрамі Ауробіндо і Мірри Рішар учням була надана широка свобода в обранні джерел, водночас було чимало обмежень стосовно дисципліни і свободи пересування.

Ще одна теза, висунута Успенським, викликала б повне схвалення Ауробіндо. Успенський стверджує, що «в основі всіх йог полягає один принцип, а саме: людина, якою вона народжена і живе, є незавершена і недосконала істота, яку однак можна змінити i розвинути за допомогою навчання і тренування» [2, с. 253]. Один із розділів книги Сатпрема, присвяченої філософії Ауробіндо, так і названо: «Людина - перехідна істота». Цікаво, що для обох, для Успенського і для Ауробіндо, це твердження обгрунтовувалося одночасно у трьох площинах. По-перше, з точки зору власне йоги, яка гарантує радикальну зміну людської свідомості за умови радикального слідування йогічним шляхом. Друга площина пов'язана 3 поглядом Ніцше на людину, як на канат між мавпою і надлюдиною, погляд, який розділяв Ауробіндо і рівною мірою розділяв i навіть цитував Успенським. Третя площина пов'язана вже не 3 йогою і навіть не з радикальними висновками з теорії еволюції, які зробив Ніцше, а саме $з$ духовним поглядом на еволюцію. Парадигма духовної еволюції об'єднувала багато в чому і Ауробіндо і Успенського, хоча погляди Ауробіндо на майбутню стадію людської еволюції були значно більш конкретними і деталізованими. 
Наступні пункти для зіставлення поглядів Успенського і Ауробіндо викристалізовуються при аналізі описів теорії і практики хатха-йоги. Успенській твердить, що якщо тіло людини не підготовлене і не треноване особливими йогічними вправами, воно не зможе впоратися 3 напруженою працею органів сприйняття і свідомості, серця, мозку, нервової системи, яка пов'язана з розвитком вищих сил і здібностей людини. Усе тіло має бути вдосконалене, гармонізоване, очищене, приведене у порядок і підготовлене до нової, колосально важкої роботи, яка його очікує.

Для того, щоб порівняти це твердження з тезами Ауробіндо, слід пам'ятати, що практика хатха-йоги не перебуває у центрі інтересів індійського мислителя. Ауробіндо вважає, що низхідна енергія взагалі не спричинить у йогіна тих проблем, які спричиняє висхідна. Водночас, він твердить про зміну тіла значно більш радикальну, ніж пропонується в хатха-йозі. У філософії йоги Ауробіндо тіло людини має справу з супраментальним Агні, енергією найвищої частоти, отже заспокоєння вітального розуму і гармонізація тіла $є$ надзвичайно необхідними для низведення цих енергій. Але відмінність від Успенського полягає в тому, що Ауробіндо і Сатпрем розмірковують тут не про хатха-йогічні асани, а саме про заспокоєння і гармонізацію функцій тіла, зняття незбалансованості функціонування органів і клітин.

Крім того, Ауробіндо твердить і про необхідність звичайних фізичних вправ. Ці вправи відігравали значну роль у практиці і житті учнів ашраму Ауробіндо в Пондішері, а один з учнів ашраму, Шрі Чінмой, підніс їх на такий кардинальний рівень, що навіть залишив шлях учня Ауробіндо та створив власну школу.

Чимало аналогій можна провести і у випадку інтерпретації Успенським системи раджа-йоги у зіставленні з інтегральним підходом Ауробіндо і Сатпрема. Успенський відзначає: «Лише оволодівши вмінням зупиняти хід своїх думок, людина може наблизитись до того, щоб чути думки інших людей, чути всі голоси, що безперервно звучать у природі, голоси «малих життів» його власного тіла, голоси «великих життів», в які входить він сам» [2, c. 261].

Своєрідна метафорична мова Успенського може бути зіставлена 3 яскраво поетичною метафорикою Сатпрема у його книзі, 110

Institute of Philosophy of H. S. Skovoroda of NAS of Ukraine 
присвяченій філософії Ауробіндо. Сатпрем на різні лади пише про зупинку «машини розуму», «ментальної фабрики», про те, що i чужі і власні думки приходять до людини іззовні, про те, що розум людини $є$ «приймальна станція», яка вловлює думки, які приходять iз ментального плану більш високого, ніж наш, а саме - із Загального Ментального. Коли йдеться про голоси малих життів власного тіла людини в Успенського, це легко зіставити з описом «фізичного розуму» в Ауробіндо і Сатпрема, голос якого у нейогіна заглушається саме ментальною мішаниною фабрики думок. А голоси «великих життів» у метафориці Успенського доречно зіставити 3 описами як Загального Ментального, так і Загального Вітального у системі Ауробіндо.

Крім того Успенський зауважує: «Коли людина навчиться за бажанням не думати, вона отримує можливість скоротити даремну й непотрібну втрату психічної енергії, що йде на непотрібне мислення... Як часто трапляється, що в розум потрапляє якась думка i

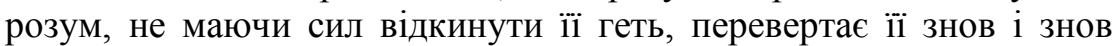
безкінечну кількість разів, як ручай перевертає камінь, що лежить на його дні» [2, с. 261].

Сатпрем цитує Ауробіндо, який стверджує, що «якщо здатність думати - це чудовий дар, то здатність не думати - дар більш великий» $[1$, с. 44]. Лише тоді йогін розуміє, що він живе в невидимому хаосі, у безперервному вихорі, який забирає частину енергії шукача. I коли Сатпрем пише: «Йога в основному це не так спосіб навчитися, як спосіб відучитися від маси неуникних, на перший погляд, звичок, які ми успадкували від нашої тваринної еволюції» $[1$, c. 52], він лише на свій лад описує думку, яку неодноразово проводить Успенський в описі хатха і раджа-йоги. Щоправда, Успенський пропонує після опису процедури «не-думання» процес зосередження розуму на спеціально обраних предметах, Ауробіндо і Сатпрем зосереджується скоріше не на розвитку нових ментальних здібностей, а на низведенні більш високих форм енергії і виході в більш високій спосіб пізнання, в максимумі - супраментальний.

Особливий інтерес являють собою аналогії між описами Успенським карма-йоги і пафосом дії у світі і в матерії у філософії Ауробіндо. Неофітові, який ознайомився лише з книгою Сатпрема, 
здається, що позиція Ауробіндо - діяти у світі, в суспільстві - це виклик традиційній йозі. Успенський, популяризуючи знання карма-йоги, стверджує, що остання вчить, як стати йогіном у житті, не віддаляючись у пустелю і не вступаючи у школу йогінів. Без урахування принципів карма-йоги, раджа-йога і хатха-йога вироджуються, на думку Успенського, у прагнення до зовнішніх чудес, до таємничого та страшного, тобто у псевдо-окультизм. Тут варто згадати описи Сатпремом чудес, які досягали Мірра Рішар і учнів в ашрамі Ауробіндо. Достатньо було легкої критики з боку Ауробіндо і практикування чудесних здібностей, яке, щоправда, Сатпрем вважає навіть не псевдо-окультним, а реально-діючим, було миттєво залишене. Шукач в інтегральній йозі Ауробіндо не має витрачати енергії навіть на чудеса.

Ще одне порівняння. Успенський стверджує, що без кармайоги бхакті-йога вироджується у псевдомістику, в марновірство, в особистісне обожнювання або прагнення до особистого спасіння. Тут є аналогії і з запереченням Ауробіндо релігійного шляху, і 3 відмовою від наміру заснувати нову релігію. Це знов таки стосується і критики з боку Ауробіндо і Сатпрема ідеї особистісного спасіння: «Ніщо не врятоване, доки не врятоване все», «Недосконала радість, не розділена всіма», «душу не потрібно «спасати», як прийнято говорити. Вона є вічно вільною і чистою, перебуваючи навічно спасенною у своєму сяєві» [1, с. 163-165]. Без карма-йоги i джнані-йога, за Успенським, вироджується у схоластику або, в кращому разі, в метафізику. Цю тезу слід зіставити 3 критикою Ауробіндо суто раціонального підходу до пізнання, проведеного, зокрема, у статті «Західна метафізика і йога».

Пошук аналогій можна було б продовжити, але, зіставляючи погляди Шрі Ауробіндо і Успенського щодо йоги, треба завжди пам'ятати, що Успенський ставить перед собою радше описові i більш аналітичні задачі; він шукав аутентичність в описі індійського, йогічного способу пізнання. А Ауробіндо постійно шукав більш синтезуючий підхід до йоги і прагнув вийти за межі як західного раціоналізму, так і традиційних описів йоги. 


\section{ЛIТЕРАТУРА}

1. Сатпрем. Шри Ауробиндо или Путешествие сознания. Л., 1989. $334 \mathrm{c}$.

2. Успенский П. Д. Новая модель Вселенной. М., 2010. 560 с.

3. Успенский П. Д. TERTIUM ORGANUM. СПб., 1992. 241 с.

4. Beckwith Gerald de Symons. Ouspensky's Fourth Way: The story of the further development and completion of P. D. Ouspensky's work by Dr Francis Roles. Oxford : Starnine Media \& Publishing Ltd, 2015. 408 p.

5. Hemsell R. The Philosophy of Consciousness: Hegel and Sri Aurobindo. E-Book, 2017. 197 p.

6. Huchzermeyer W. Sri Aurobindo's Commentaries on Krishna, Buddha, Christ and Ramakrishna. Their Role in the Evolution of Humanity. Edition sawitri. E-Book, 2018. 99 p.

7. Johnston D. T. Jung's Global Vision: Western Psyche, Eastern Mind, With References to Sri Aurobindo, Integral Yoga, The Mother. Agio Publishing House, 2016. 547 p.

8. Johnston D. T. Prophets in Our Midst: Jung, Tolkien, Gebser, Sri Aurobindo and the Mother. Universe, E-Book, 2016. 222 p.

9. Llewellyn J. E. The Modern Bhagavad Gītā: Caste in TwentiethCentury Commentaries. International Journal of Hindu Studies. 2019. Vol. 23. P. 309-323.

\section{REFERENCES}

Satprem. (1989). Sri Aurobindo or The Adventure of Consciousness. Leningrad, Publisher of the Leningrad university. [In Russian].

Ouspensky, P. D. (2010). A New Model of the Universe. Moscow. [In Russian].

Ouspensky, P. D. (1992). Tertium Organum. St. Petersburg. [In Russian].

Beckwith, Gerald de Symons. (2015). Ouspensky's Fourth Way: The story of the further development and completion of P. D. Ouspensky's work by Dr. Francis Roles. Oxford: Starnine Media \& Publishing Ltd.

Hemsell, R. (2017). The Philosophy of Consciousness: Hegel and Sri Aurobindo. E-Book.

Huchzermeyer, W. (2018). Sri Aurobindo's Commentaries on Krishna, Buddha, Christ and Ramakrishna. Their Role in the Evolution of Humanity. edition sawitri. E-Book. 